\title{
Andrzej Offmański (red.), Malżeństwo i rodzina w panoramie współczesnych systemów, wyd. Wydział Teologiczny Uniwersytetu Szczecińskiego, Szczecin 2006, 262 s.
}

Do najważniejszych właściwości małżeństwa należy zaliczyć jego trwałość, która stanowi podstawę funkcjonowania rodziny. Sakrament małżeństwa oraz wzajemna więź małżonków przenikają każdą sferę ich życia i stanowią podstawę budowania wspólnoty rodzinnej oraz warunkują uczestnictwo rodziny w rozwoju społeczeństwa i jej udział w misji Kościoła. W małżeństwie powstaje nowa jakość, gdyż dwie osoby, kobieta i mężczyzna, wchodzą w ścisłą relację i zachodzi pomiędzy nimi swoista jedność. Należy wskazać, że do jednego z pierwszych zadań rodziny należy wierne przeżywanie rzeczywistości komunii i to w nieustannym działaniu na rzecz rozwijania wspólnoty osób: kobiety i mężczyzny jako małżonków, a także ich dzieci, dziadków i innych bliskich. Trwająca w małżeństwie miłość między żoną i mężem oraz miłość między wszystkimi członkami rodziny, winna być podtrzymywana i ożywiana przez wewnętrzny, nieustający dynamizm, który prowadzi wspólnotę rodzinną do coraz głębszej komunii, będącej fundamentem i zasadą wspólnoty małżeńskiej i rodzinnej.

Dlatego na tym gruncie, a także w świetle różnych współczesnych prób patrzenia i rozumienia małżeństwa i rodziny, należy zauważyć książkę Małżeństwo i rodzina w panoramie współczesnych systemów, która powstała pod redakcją ks. dr. hab. Andrzeja Offmańskiego, profesora nadzwyczajnego Uniwersytetu Szczecińskiego. O wspomnianych kontekstach napisał także redaktor we Wprowadzeniu do omawianej publikacji: „W tym przejściu od społeczeństwa tradycyjnego poprzez nowoczesne do ponowoczesnego radykalnie się zmienia sytuacja społeczna, moralna i religijna, bez całościowej wizji życia porządkującej hierarchię wartości. W tym kontekście rodzi się fundamentalne pytanie: jak w obecnej sytuacji społeczno-kulturowej odnajduje się małżeństwo i rodzina, zwłaszcza rodzina chrześcijańska? Indywidualizacja bowiem rozciąga się na wszystkie dziedziny myślenia i działania. Cywilizacje współczesne wykazują swoisty kryzys będący wynikiem braku zaufania do dotychczas istniejących autorytetów: Boga, ojczyzny, rodziny. Powoduje to żywiołowy proces fragmentaryzacji i dezintegracji”".

Omawiana praca zbiorowa jest pokłosiem zorganizowanego w 2005 roku w Szczecinie sympozjum w 30. rocznicę działalności Instytutu Studiów nad

Małżeństwo i rodzina w panoramie współczesnych systemów, A. Offmański(red.), Szczecin 2006 s. 8. 
Rodziną w Łomiankach. Recenzję wydawniczą niniejszej publikacji przygotował dr hab. Krystian Wojaczek, prof. UO. Prezentowana książka, wydana przez Wydział Teologiczny Uniwersytetu Szczecińskiego, licząca 262 strony, składa się z wprowadzenia Redaktora, czterech zasadniczych części zawierających trzynaście artykułów oraz noty o autorach.

W pierwszej części Rodzina wobec współczesności Autorzy dwóch tekstów (B. Mierzwiński, Czy zmierzch instytucji rodziny?; K. Wolski, Świadomość znaczenia chrześcijańskiego małżeństwa) zaprezentowali małżeństwo i rodzinę w świetle czasów współczesnych. Ukazali niepowtarzalną wartość rodziny jako podstawowej komórki Kościoła i państwa oraz podkreślili, że jest ona kolebką życia i szkołą człowieczeństwa. Wskazano również, że małżeństwo jest sprawą międzyludzką, Bosko - ludzką i społeczną.

Natomiast w drugiej części Systemy relacji rodzinnych znajdują się trzy artykuły (Z. Kroplewski, Jednostka czy rodzina?; M. Ryś, Znaczenie relacji w rodzinie. Wpływ oddziaływania prawidłowych i nieprawidłowych systemów rodzinnych; I. Rawicka, Samotna matka dzisiaj). Przypominając o tym, że człowiek do pełnego rozwoju potrzebuje rodziny, zaprezentowano różne relacje zachodzące w rodzinie, różne systemy i koncepcje stosunków rodzinnych. Podkreślono, że życie każdego człowieka zależy od tego, jaki system funkcjonowania prezentuje rodzina, w której dorasta. Została uwypuklona także potrzeba otrzymywania przez dziecko ciepła zarówno ze strony matki jak i ojca.

W części trzeciej Pastoralna posługa rodzinie znajdziemy sześć tekstów (G. Dammacco, Rodzina w systemie prawa kanonicznego; U. Harder, Zapobieganie separacji i rozwodom. Nowe perspektywy duszpasterstwa małżeństw; J. Sz. Szymczak, Troska Kościoła o współczesna rodzinę; K. Półtorak, Apostolskie zadania rodziny ewangelizowanej oraz ewangelizującej; J. Stala, Wychowanie do małżeństwa i rodziny na miare XXI wieku; A. Offmański, Katechetyczna posługa Kościoła $w$ Polsce wobec rodziny). Omówiono aktualne pojmowanie prawne rodziny w systemie prawa kanonicznego, sprawę zapobiegania separacji i rozwodom oraz nowe perspektywy duszpasterstwa małżeństw i rodzin, aby rodzina mogła odnaleźć samą siebie wśród gwałtownych zmian zachodzących współcześnie. Zauważono również, że Kościół zawsze uznawał służbę rodzinie jako jedno $\mathrm{z}$ najważniejszych swych zadań oraz przypomniano katechetyczną posługę wobec rodziny. Biorąc pod uwagę współczesne zagrożenia małżeństwa i rodziny wskazano również na potrzebę integralnego i skutecznego wychowania do małżeństwa i rodziny.

W ostatniej, czwartej, części Kulturowe aspekty wizji rodziny zostały zamieszczone dwa teksty (K. Łuszczek, Dziecko w krajobrazie medialnym; G. Zaccaro, Natalia Ginzburg opowiada o rodzinie). Zostały omówione ogromne wpływy mediów na wychowanie dzisiejszego młodego pokolenia, co często skutkuje osłabieniem więzi międzypokoleniowych i utratą autorytetów rodziców. Za- 
mieszczono również interpretację opowiadania o rodzinie Natalii Ginzburg, która zauważa swoje życie w kontekście dynamiki rodzinnej.

Przy każdym tekście została dołączona wybrana literatura, co może być pomocne $\mathrm{w}$ dalszych poszukiwaniach. Nadto artykuły zostały opatrzone streszczeniami w języku niemieckim i włoskim, co z pewnością ułatwi niemiecko- i włoskojęzycznym poszukiwaczom zapoznać się z omawianą publikacją. Natomiast z zamieszczonych not biograficznych dowiadujemy się o Autorach niniejszej publikacji.

Wydaje się, iż prezentowana książka, m.in. ze względu na swoją aktualność i poruszane $\mathrm{w}$ niej zagadnienia, jest interesująca i skierowana zarówno do młodzieży przygotowującej się do przyjęcia sakramentu małżeństwa, młodych małżonków i rodziców oraz już żyjących przez wiele lat w związku małżeńskim, jak i do nauczycieli, pedagogów, katechetów, nauczycieli religii, duszpasterzy oraz studentów i specjalistów podejmujących badania nad małżeństwem i rodziną, a więc do wszystkich, którzy są zainteresowani - od strony teoretycznej jak i praktycznej - dojrzałym i odpowiedzialnym spojrzeniem na sprawy małżeństwa i rodziny. Podkreślono to we Wprowadzeniu: „Opracowania zamieszczone w niniejszym zbiorze pochodzą od teologów, psychologów, prawników kanonistów, ale też pedagogów, znawców mediów, a nawet teoretyków literatury. Autorzy ci w przeważającej liczbie reprezentują katolicką wizję rodziny, ale też są wśród nich poszukujący perspektyw pomocy rodzinie na gruncie teologii, praktyki pastoralnej katolickiej i protestanckiej. Poznanie tych rozmaitych punktów widzenia pozwoli, jak sądzimy, stwierdzić, na ile problem małżeństwa i rodziny jest dziś uznawany za szczególnie ważny i wymagający jeszcze większego zgłębiania i rozwiązywania. Można mieć nadzieję, że zbiór opracowań oddawany do rąk czytelników stanowić będzie przyczynek do znalezienia wspólnej płaszczyzny aksjologicznej i teologicznej nauk o małżeństwie i rodzinie, nauk, które pragną posłużyć tym instytucjom w odnalezieniu ich miejsca w przekształcającym się społeczeństwie i w dynamicznym zaangażowaniu w jego rozwój" ${ }^{2}$. Bowiem małżeństwo i rodzina jest wyrazem planu Bożego, a małżeństwo i rodzina zbudowane na zaufaniu i silnym fundamencie sakramentu małżeństwa oraz miłości małżeńskiej, może się ustrzec od współczesnych zagrożeń. Rodzina jest podstawową komórką społeczną, dlatego podstawy w niej wykształcone współdecydują o późniejszym systemie funkcjonowania rodziny i społeczeństwa. Bowiem niezwykle jest trudny proces wychowania do małżeństwa i rodziny bez małżeństwa i zdrowej rodziny.

ks. Józef Stala Uniwersytet Jana Pawła II w Krakowie

2 Tamże, s. 9-10. 